\title{
ADNEXAL TORSION FOLLOWING GONADOTROPIN- RELEASING HORMONE ANALOG THERAPY: A CASE REPORT
}

\author{
Jesus Paula Carvalho, Mara Solange Diegoli, Filomena Marino Carvalho and \\ Carlos Alberto Diegoli
}

CARVALHO JP et al. Adnexal torsion following gonadotropin-releasing hormone analog therapy: a case report. Rev. Hosp. Clín. Fac. Med. S. Paulo 59(3):128-130, 2004.

Adnexal torsion may occur in girls and adolescents. Often it is associated with ovarian diseases resulting in ovarian enlargement. Adnexal torsion may involve the ovary, fallopian tube or both, and the main sympton is acute pelvic pain.

An 8-year-old girl complaining of acute pelvic and abdominal pain, who was previously diagnosed with precocious puberty and who received treatment with a GnRH analog, is reported.

Ultrasound demonstrated a normal-sized uterus and bilaterally enlarged ovaries with multiple internal cysts. At laparotomy, we found a complete torsion in the right adnexa.

The histological examination revealed massive edema associated with multiple antral follicles and reduction of the follicular reserve.

KEY WORDS: Ovarian neoplasms. Adnexal torsion. Precocious puberty. GnRH analog.

Ovarian torsion is an uncommon cause of abdominal pain in children and teenagers. However, in several series of children with ovarian masses, torsion was at least a component of the final diagnosis in 5 to 17 percent of the cases. Torsion of the ovary initially interferes with venous and lymphatic circulation, so there is sudden growth of the adnexa because of congestion and edema. If the torsion is unrelieved, the arterial supply may eventually be compromised-a condition that can lead to ovarian necrosis and peritonitis, mandating early surgical intervention ${ }^{2}$.

Adnexal torsion may involve the ovary, fallopian tube, ${ }^{2}$ or both. Ovarian enlargement of any cause is a predisposing condition for adnexal torsion. It may occur in any age group, including prepubertal girls, ${ }^{2-5}$ and the diagnosis must be included in the differential diagnosis for girls and teenagers with acute pelvic pain.

The right side is affected more frequently than the left ${ }^{2}$. Because symptoms are nonspecific, the diagnosis may be confused with pelvic inflammatory disease or appendicitis. ${ }^{2}$ Nausea and vomiting are frequent symptoms, and fever and leukocytosis are occasionally present.

A case of adnexal torsion following $\mathrm{GnRH}$ analog treatment for preco-

From the Gynecologic Oncology Service, Gynecologic Adolescent Service, Pathology Division and Gynecologic Emergency Service, Hospital das Clínicas, Faculty of Medicine, University of São Paulo - São Paulo/SP, Brazil.

E-mail: carvalhojp@uol.com.br Received for publication on July 29, 2003. cious puberty in a patient with unsuspected McCune-Albright syndrome is reported.

\section{CASE REPORT}

An eight year girl, height $145 \mathrm{~cm}$, was referred to our hospital complaining of acute pelvic and abdominal pain. There was no history of fever, urination changes, weight loss, or diarrhea. In the previous 12 hours she had presented some episodes of nausea and vomiting.

The mother reported that the girl had experienced breast development since the age of 4 .

Five months previously, serum estradiol had been measured at $23 \mathrm{pg} /$ $\mathrm{mL}$. The diagnosis of precocious pu- 
berty was made, and the patient was treated with leuprolide acetate $3.6 \mathrm{mg}$ once a month. Three days after the third injection of leuprolide, the patient developed abdominal pain, nausea and vomiting, and abdominal enlargement, and she was then referred to our institution. At that time, an ultrasound exam revealed bilateral ovarian enlargement.

On physical examination, she had a protuberant pelvic mass that extended above the umbilicus as well as diffuse café-au-lait spots in the forearm and tibial regions. With these findings, we suspected McCune-Albright syndrome complicated with adnexal torsion. Ultrasound reveals a uterine volume of $28 \mathrm{~cm}^{3}$, a right adnexal mass of $18 \mathrm{~cm}$ in diameter and volume of $857 \mathrm{~cm}^{3}$, and multiple internal cysts.

The patient underwent laparotomy. The right adnexa had a complete torsion (Figure 1), and the right ovary presented areas of necrosis and multiple cysts (Figure 2). The left ovary was also enlarged (about $7 \times 5 \times 4 \mathrm{~cm}$ ) with multiple cysts, but without torsion or areas of necrosis. A right salpingooophorectomy was performed. The histological examination revealed massive edema associated with multiple antral follicles and reduction of the follicular reserve. The patient recovered well from the surgery.

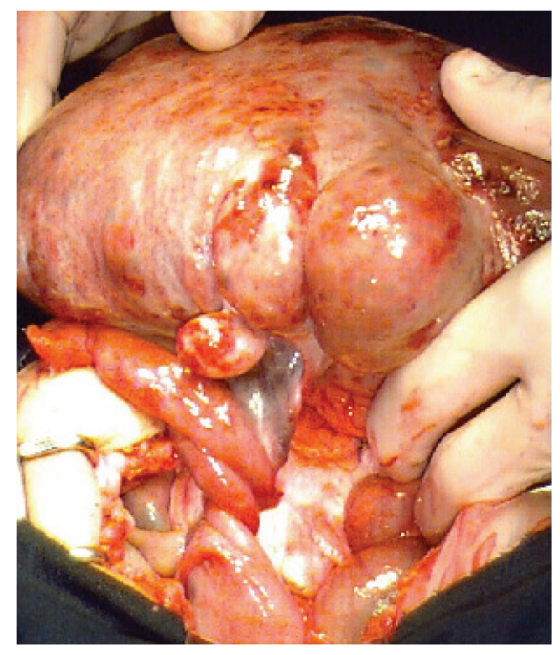

Figure 1 - Right adnexa with torsion.
One month later, a follow-up ultrasound exam revealed that the remaining left ovary was still enlarged, and we chose to treat her with medroxyprogesterone $150 \mathrm{mg}$, intravenously, every 2 months for the next 2 years. During this period, the patient presented 2 episodes of uterine bleeding. At the age of 10 , the medroxyprogesterone regime was interrupted, and the patient experienced 1 year of amenorrhea.

At the age of 11, irregular menses began, and we started a regime of norethindrone acetate from the 15 th to 24th day of the menstrual cycle. Two years later, the patient has eumenorrhea and continues with this regime. She is $155 \mathrm{~cm}$ in height and weighs $52 \mathrm{~kg}$.

\section{DISCUSSION}

McCune-Albright syndrome is characterized by irregular café-au-lait spots, polyostotic fibrous dysplasia, and GnRH-independent precocious puberty. It is caused by a mutation in the alpha-subunit of the stimulatory Gprotein, producing constitutive activation. ${ }^{2}$ Mutations of the GS-alpha subunit of the $G$ protein, which couples extracellular hormonal signals to the activation of adenylate cyclase, are responsible for the autonomous hyperfunction of the endocrine glands and, presumably, for the other defects present in this disorder. ${ }^{2}$

Sexual maturation in these instances may be due to extrapituitary secretion of human chorionic gonadotropin (HCG) or sex steroid secretion independent of hypothalamic-pituitary gonadotropin stimulation.

Girls develop sexual precocity as a result of functioning ovarian cysts. Breast development and vaginal bleeding, which may be periodic, are related to intermittent increases in estradiol levels in association with 1 or more ovarian cysts. LH and FSH levels are prepubertal. Excessive hormone production by the thyroid, adrenal, and parathyroid may occur. The diagnosis is made on the basis of skin pigmentation and demonstration of bone lesions or pathologic fractures. Treatment of the McCune-Albright syndrome involves use of testolactone, spironolactone, and ketoconazole. ${ }^{2}$

In spite of the rarity of this syndrome, it represents almost $10 \%$ of the precocious puberty cases. The bilateral increase of the ovarian volume can result in adnexal torsion, abdominal pain, hemorrhage, necrosis of the ovary, and loss of the gonads. The use of a GnRH analog, does not relieve the symptoms. At first, the GnRH analog

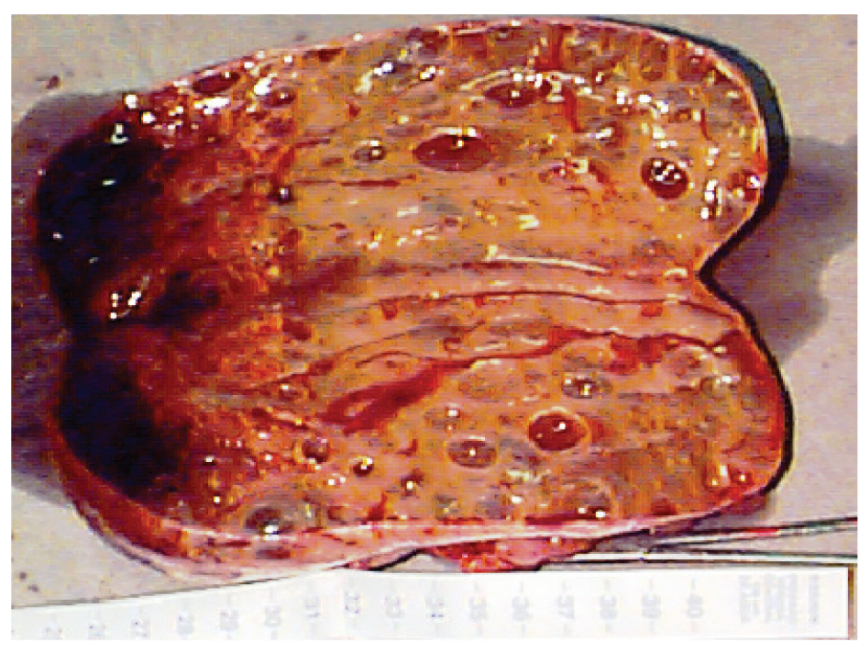

Figure 2 - The enlarged ovary with areas of necrosis and multiple cysts. 
may stimulate FSH and LH secretion, resulting in ovarian stimulation, cyst formation, increase of volume and adnexal torsion.

The use of $150 \mathrm{mg}$ medroxyprogesterone acetate every 2 months until the expected beginning of the menses and a regime of norethindrone acetate from the 15th to 24th day of the menstrual cycle after the establish- ment of the periods seems to be a good option for treatment.

\section{CONCLUSION}

McCune-Albright syndrome is a very rare disease characterized by irregular café-au-lait spots, polyostotic fibrous dysplasia, and GnRH-inde- pendent precocious puberty. The enlarged ovaries predispose the individual to develop adnexal torsion. It is very important to recognize this syndrome before $\mathrm{GnRH}$ analog treatment for precocious puberty because treatment with a GnRH analog can increase the risk of adnexal torsion by the initial stimulatory effect of this drug on the ovaries.

\section{RESUMO}

CARVALHO JP e col. Torção Anexial após tratamento da Síndrome de Mcune-Albright com Agonista de GnRH. Relato de Caso. Rev. Hosp. Clin. Fac. Med. S. Paulo 59(3): 128-130, 2004.

Torção anexial pode ocorrer em crianças e adolescentes do sexo feminino. Frequentemente está associada com doenças ovarianas que resultam em cres- cimento da gônada. A torção anexial pode comprometer os ovários isoladamente, as tubas uterinas ou ambos e o sintoma principal é dor pélvica aguda.

Descrevemos um caso de dor pélvica aguda em uma menina de 8 anos de idade, com diagnóstico prévio de puberdade precoce e que estava em tratamento com análogo de GnRH.

O exame ultra-sonográfico demonstrava útero de tamanho normal com ovários aumentados bilateralmente e múltiplos cistos. Na laparotomia foi encontrado torção completa do anexo direito. $\mathrm{O}$ exame histológico demonstrou edema maciço de ovário associado com múltiplos cistos antrais e redução da reserva folicular.

UNITERMOS: Neoplasia de ovário. Torsão anexial. Puberdade precoce. Agonista de GnRH. Cirurgia.

\section{REFERENCES}

1. McGee DM, Connolly SA, Young RH. Weekly clinicopathological exercises. Case 24-2003. A 10-year-old girl with recurrent bouts of abdominal pain. New England Journal of Medicine 2003;349:486-94.

2. Ferrera PC, Kass LE, Verdile VP. Torsion of the fallopian tube. Am J Emerg Med 1995;13:312-4.

3. Ben-Arie A, Lurie S, Graf G, Insler V. Adnexal in adolescents: prompt diagnosis and treatment may save the adnexa. Eur J Obstet Gynecol Reprod Biol 1995;63:169-73.

4. Fleischer AC, Stein SM, Cullinan JA, Warner MA. Color doppler sonography of adnexal torsion. J Ultrasound Med 1995; $14: 523-8$

5. Bader T, Ranner G, Haberlik A. Torsion of normal adnexa in a premenarcheal girl: MRI findings. Eur Radiol 1996;6:704-6.

6. Cohen Z, Shinhar D, Kopernik G, Mares AJ. The laparoscopic approach to uterine adnexal torsion in childhood. J Pediatr Surg 1996;31:1557-9.
7. Steyaert H, Meynol F, Valla JS. Torsion of the adnexa in children: the value of laparoscopy. Pediatr Surg Int 1998;13:384-7.

8. Maynard SR, Peipert JF, Brody JM. Tubal torsion appearing as acute pelvic inflammatory disease. J Am Assoc Gynecol Laparosc 1996;3:431-3.

9. Shust NM, Hendricksen DK. Ovarian torsion: an unusual case of abdominal pain in a young girl. Am J Emerg Med 1995;13:307-9.

10. DiMeglio LA, Prescovitz OH. Disorders of puberty: inactivating and activating molecular mutations. J Pediatr 1997;131:S812 .

11. Weinstein LS, Shenker A, Gejman PV, Merino MJ, Friedman E, Spiegel AM. Activating mutations of the stimulatory $G$ protein in the McCune-Albright syndrome. $N$ Engl J Med 1991;325:1688-95.

12. Wheeler MD. Update on therapy for precocious puberty. Compr Ther 1994;20:351-5. 